\title{
Maternal Smoking and Fetal Growth of Full Term Infants
}

\author{
HERBERT C. MILLER ${ }^{(25)}$ AND KHATAB HASSANEIN
}

Departments of Pediatrics and Biometry, University of Kansas Medical Center, Kansas City, Kansas, USA

\section{Extract}

Maternal smoking during pregnancy was associated with reductions in birth weights and crown-heel lengths, but not in ponderal indices of four groups of full term infants. The reductions in crown-heel lengths were statistically significant in three of the four groups of infants. The effects of smoking on fetal growth did not appear to be related to poor maternal nutrition. Mean weight gains during the last two trimesters of pregnancy were not significantly different in smoking and nonsmoking mothers and were above the mean weight gains recommended by the National Research Council.

\section{Speculation}

The effects of smoking and poor maternal nutrition, as measured by low weight gains during the last two trimesters of pregnancy, are about the same with respect to linear growth of the fetal skeleton, but differ with respect to ponderal indices. Ponderal indices are not affected by smoking but tend to be markedly reduced if maternal weight gains during pregnancy are low.

Smoking by mothers during pregnancy has been associated with a reduction in mean birth weight of their infants in all reported studies. The Surgeon General of the United States found that the reduction in mean birth weight in over 100,000 infants of smoking mothers reported in 18 studies was $173 \mathrm{~g}$ (22). In individual reports, reductions in mean birth weights of infants of smoking mothers ranged from $40-400 \mathrm{~g}(15,16)$. The present study was undertaken to determine the nature of the reduction in birth weight. There were three possible explanations. The gestational period might be shortened; linear growth of the fetal skeleton might be reduced; or the ratio of fetal body weight to body length might be diminished, which suggests a reduction in soft tissue mass.

No evidence was found in several studies to support the hypothesis that the gestational period of smoking mothers was significantly shorter than for nonsmoking mothers $(1,4,7,9$, $17,18,21,23,24)$. Reductions in mean crown-heel lengths of infants of smoking mothers were reported in two studies. In one study, the reductions in mean body lengths of infants of smoking mothers were significantly greater than in infants of nonsmoking mothers (6). In the other study, no statistical interpretation was given on the observed differences in body length (8)...To our knowledge, no reports have appeared on the effects of smoking on the ponderal index (ratio of body weight to body length) of newborn infants. In the present study, the effects of maternal smoking and other selected independent variables on birth weight, crown-heel length, head circumference, and ponderal index were investigated.

\section{MATERIALS AND METHODS}

All mothers were Caucasian and delivered consecutively of single infants at the University of Kansas Medical Center. In order to reduce the total number of independent variables, mothers with any of the following conditions were excluded from the study: failure to have a spontaneous onset of labor, failure to complete at least 36 weeks of pregnancy, maternal height less than 61 or more than 66 inches, a prepregnancy weight more than $30 \%$ above or $15 \%$ below the average weight for height as determined from Sargent's height-weight table for young women (20), a weight gain of less than 0.5 pound/week on the average in the last two trimesters, complications of pregnancy (pre-eclampsia, diabetes mellitus, or severe vaginal bleeding), major disease (chronic hypertension, chronic impairment of renal function, cancer, decompensated heart disease, epilepsy treated with dilantin or phenobarbital, chronic alcoholism, taking hard drugs, severe asthma treated with prednisone, and any other chronic debilitating disease). Mothers were also excluded if their infants had hemolytic disease caused by blood group incompatibility, clinically recognizable congenital malformations, or intrauterine infections.

Maternal weight gain during pregnancy was calculated in mean pounds gained per week during the last two trimesters of pregnancy from weights recorded at prenatal visits. In order to qualify for the study, prenatal visits by mothers had to cover more than 10 weeks of the last two trimesters and the last prenatal visit had to be within 2 weeks of delivery. All mothers were interviewed by one of us $(H C M)$ following delivery and before discharge from hospital in order to obtain information on the amount of smoking during pregnancy and to check information obtained from their medical and obstetrical records. Mothers were placed in the smoking group if they smoked any cigarettes during any part of pregnancy. Mothers were divided into two social classes, as follows: mothers were placed in high social class if they could pay all of their hospital expenses and in low social class if they were on welfare or could not pay full hospital costs.

Infants were weighed and measured at birth according to methods reported previously from this clinic (12). All infants were examined and measured by one of us $(H C M)$. The ponderal index of each infant was calculated according to Rohrer's formula: weight in grams $\times 100 \div$ cube of crown-heel length in centimeters (19).

Step-wise multiple regression analyses were used to analyze the data for each of four groups of infants. There were four dependent variables, including birth weight, crown-heel length, head circumference, and ponderal index. In our analysis, variables were not allowed to enter the analysis or were later dropped from the analysis whenever their $F$ values dropped below the $25 \%$ probability level. This procedure eliminated variables having very little association with the outcome (dependent variables) and also eliminated variables whose association with the dependent variables was less than their association with another independent variable. At each step, one variable was added to the regression equation. The variable added was the one which made the greatest reduction in the error sum of squares. Equivalently, it was the variable which, if added, would have had the highest $F$ value. 
Table 1. Mean and standard deviations of 10 selected variables in four groups of infants

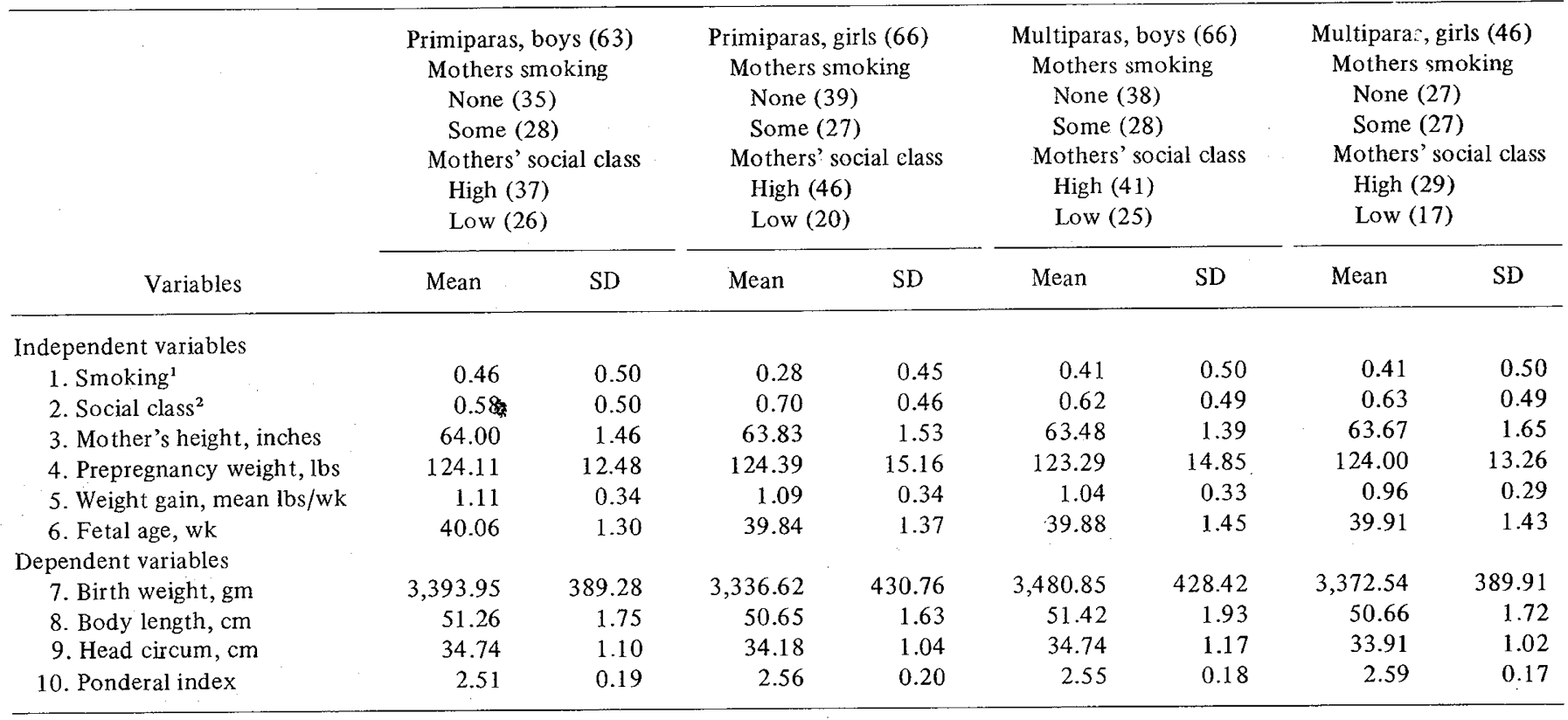

${ }^{1}$ Nonsmokers $=0 ;$ smokers $=1$.

${ }^{2}$ Low social class $=0 ;$ high social class $=1$.

\section{RESULTS}

The means and standard deviations of 10 variables are shown in Table 1 . The results of the multiple regression analysis on outcome in four groups of infants are shown in Table 2. Maternal smoking tended to decrease birth weights in all four groups of infants (see Table 3 ), but the decreases were not statistically significant. Smoking had a statistically significant effect in reducing crown-heel length of girls born to multiparas $(P<0.05)$ and of boys born to primiparas $(P<$ $0.01)$ and multiparas $(P<0.01)$ and in reducing head circumferences of girls born to primiparas $(P<0.05)$ and multiparas $(P<0.05)$. Smoking did not have a statistically significant effect on ponderal indices in any of the four groups of infants. When high social class was given a value of 1 and low social class was given a value of 0 , high social class had no statistically signficant effect on outcome except to increase birth weights and body lengths of boys born to primiparas $(P$ $<0.05)$ and the birth weights of girls born to primiparas $(P<$ $0.01)$. Greater maternal height was associated with a statistically significant increase in birth weights and body lengths of boys and girls born to multiparas $(P<0.01$ in each case) and in head circumferences of girls born to multiparas $(P<0.01)$. Increased prepregnancy weight had no statistically significant effect on outcome except to increase head circumferences of boys born to multiparas $(P<0.01)$ and ponderal indices of girls born to primiparas $(P<0.05)$. Increased weight gain during pregnancy had no statistically significant effect on outcome except to increase ponderal indices of boys born to primiparas and : multiparas $(P<0.05)$ : Greater fetal age increased birth weights in all four groups of infants $(P<0.05)$, and body lengths in all four groups of infants $(P 0.01)$, and head circumferences in all groups $(P<0.01)$ except girls born to multiparas. Greater fetal age had no statistical effect on ponderal indices in any of the four groups of infants.

Comparisons were made between smoking and nonsmoking mothers in both high and low social classes with respect to the means of their (1) maternal ages, (2) heights, (3) prepregnancy weights, (4) number of years of schooling completed, (5) weight gained during pregnancy, and (6) completed weeks of pregnancy in each of the four groups of infants. In the high social class, no statistically significant differences in any of the
Table 2. Effect of six independent variables on four body measurements in four groups of infants ${ }^{1}$

\begin{tabular}{|c|c|c|c|c|c|c|}
\hline \multirow[b]{2}{*}{$\begin{array}{c}\text { Body measurements } \\
\text { in four groups of } \\
\text { infants }\end{array}$} & \multicolumn{6}{|c|}{ Independent variables } \\
\hline & Smoking & $\begin{array}{c}\text { Social } \\
\text { class }\end{array}$ & $\begin{array}{c}\text { Maternal } \\
\text { ht }\end{array}$ & $\begin{array}{c}\text { Pre- } \\
\text { preg- } \\
\text { nancy } \\
\text { wt }\end{array}$ & $\begin{array}{l}\text { Weight } \\
\text { gains, } \\
\text { lb/wk }\end{array}$ & $\begin{array}{c}\text { Fetal } \\
\text { age }\end{array}$ \\
\hline \multicolumn{7}{|l|}{ Birth weight } \\
\hline \multicolumn{7}{|l|}{ Primiparas } \\
\hline Boys & 1 & 2 & 1 & 1 & 1 & 2 \\
\hline Girls & 1 & 3 & 1 & 1 & 1 & 2 \\
\hline \multicolumn{7}{|l|}{ Multiparas } \\
\hline Boys & 1 & 1 & 3 & 1 & 1 & 2 \\
\hline Girls & 1 & 1 & 3 & 1 & 1 & 2 \\
\hline \multicolumn{7}{|l|}{ Body length } \\
\hline \multicolumn{7}{|l|}{ Primiparas } \\
\hline Boys & 1 & 2 & 1 & 1 & 1 & 3 \\
\hline Girls & 2 & 1 & 1 & 1 & 2 & 3 \\
\hline \multicolumn{7}{|l|}{ Multiparas } \\
\hline Boys & 3 & 1 & 3 & 1 & 1 & 3 \\
\hline Girls & 3 & 1 & 3 & 1 & 1 & 3 \\
\hline \multicolumn{7}{|l|}{ Head circumference } \\
\hline \multicolumn{7}{|l|}{ Primiparas } \\
\hline Boys & 1 & 1 & 1 & 1 & 1 & 3 \\
\hline Girls & 2 & 1 & 1 & 1 & 1 & 3 \\
\hline \multicolumn{7}{|l|}{ Multiparas } \\
\hline Boys & 1 & 1 & 1 & 3 & 1 & 3 \\
\hline Girls & 2 & 1 & 3 & 1 & 1 & 1 \\
\hline \multicolumn{7}{|l|}{ Ponderal index } \\
\hline \multicolumn{7}{|l|}{ Primiparas } \\
\hline Boys & 1 & 1 & 1 & 1 & 2 & 1 \\
\hline Girls & 1 & 1 & 1 & 2 & 1 & 1 \\
\hline \multicolumn{7}{|l|}{ Multiparas } \\
\hline Boys & 1 & 1 & 1 & 1 & 2 & 1 \\
\hline Girls & 1 & 1 & 1 & 1 & 1 & 1 \\
\hline
\end{tabular}

${ }^{1} P>0.05$

${ }^{2} P<0.05$.

${ }^{3} P<0.01$ 
Table 3. Effect of maternal smoking on mean body measurements of newborn infants

Reductions in body measurements of infants of smoking mothers ${ }^{1}$

\begin{tabular}{|c|c|c|c|c|c|c|c|c|}
\hline Infants & $\begin{array}{l}\text { Birth } \\
\text { wt, g }\end{array}$ & $P$ & $\begin{array}{l}\text { Crown-heel } \\
\text { length, cm }\end{array}$ & $P$ & $\begin{array}{c}\text { Head } \\
\text { circumference, } \\
\mathrm{cm}\end{array}$ & $P$ & $\begin{array}{l}\text { Ponderal } \\
\text { index }\end{array}$ & \\
\hline \multicolumn{9}{|c|}{ Primiparas } \\
\hline Boys & 63.0 & 2 & 0.45 & 2 & 0.14 & 2 & 0.02 & 2 \\
\hline Girls & 127.0 & 2 & 0.88 & $<0.05$ & 0.46 & $<0.05$ & 0.0 & 2 \\
\hline \multicolumn{9}{|l|}{ Multiparas } \\
\hline Boys & 179.0 & 2 & 0.78 & $<0.01$ & 0.42 & 2 & 0.04 & 2 \\
\hline Girls & 140.0 & 2 & 1.16 & $<0.01$ & 0.58 & $<0.05$ & 0.07 & 2 \\
\hline
\end{tabular}

${ }^{1}$ Compared with infants of nonsmoking mothers.

${ }^{2} P>0.05$.

six maternal conditions were found between smoking and nonsmoking primiparous mothers of boys or girls and multiparous mothers of girls. The mean prepregnancy weights and number of school years completed were significantly higher in nonsmoking than in smoking multiparous mothers of boys; there were no signficant differences in the other four maternal conditions between smoking and nonsmoking multiparous mothers of boys. In the low social class, no signficant differences were found between smoking and nonsmoking mothers, either primiparas or multiparas, with respect to any of the six maternal conditions.

\section{DISCUSSION}

Smoking by gravida in the present study was associated with reductions in birth weights, crown-heel lengths, but not ponderal indices of newborn infants. The effects of smoking on fetal growth differ apparently from the effects of poor maternal nutrition, as measured by low maternal weight gains during the last two trimesters of pregnancy. Weight gains of less than 0.5 pound/week on the average in the last two trimesters were significantly associated with the birth of full term infants in this clinic with reduced birth weights and crown-heel lengths and severe reductions in ponderal indices $(13,14)$. The reductions in crown-heel lengths of the latter infatnts were approximately of the same degree as observed in full term infants in the present study who were born to smoking mothers. Mothers who gained less than 0.5 pound/ week on the average in the last two trimesters were excluded from the present study. The weight gains of smoking and nonsmoking mothers were not significantly different and were about 1 pound/week on the average; well above the 0.8 pound/week recommended for the last two trimesters by the National Research Council (10).

The use of low maternal weight gains to evaluate maternal nutrition is based on the concept of "net weight loss" set forth by Eastman and Jackson (3). They calculated that the combined weights of the full term fetus, placenta, and amniotic fluid and the increase in weights of maternal uterus, breasts, and blood amounted to 14 pounds on the average. A mother gaining less than 14 pounds in a term pregnancy was liable to a net weight loss. Mean weight gains of less than 0.5 pound/week in the last two trimesters closely approximates the concept of a "net weight loss" by the mother.

Conflicting opinions exist concerning whether the reduction in crown-heel lengths noted at birth in infants of smoking mothers are transitory or not. The reductions in crown-heel lengths have been reported as transitory in two studies $(6,8)$ and as not transitory in one study $(2,5)$. In the latter report, the mean height of children born to smoking mothers was 1 $\mathrm{cm}$ less at age 7 years than the mean height of children of nonsmokers. Full acceptance of the validity of this difference is marred by the method used in measuring heights of children. Nurses were asked to measure height to the nearest inch, which is 2.5 times the observed difference. The transitory or permanent nature of the reduction in crown-heel length at birth of infants of smoking mothers needs further study for the added reason that some infants of smoking mothers may have been affected more than most. Studies in this clinic suggest that the reductions in crown-heel lengths of some infants of smoking mothers are at or below the 3rd percentile for their fetal ages (11). Follow-up studies of these infants with exceptionally low body lengths born to smoking mothers have not been reported.

\section{REFERENCES AND NOTES}

1. Buncher, C. R.: Cigarette Smoking and duration of pregnancy. Amer. J. Obstet. Gynecol., 103: 942 (1969).

2. Butler, N. R., and Goldstein, H.: Smoking in pregnancy and subsequent child development. Brit. Med. J., 4: 573, (1973).

3. Eastman, N. J., and Jackson, E.: Weight relationships in pregnancy. Obstet. Gynecol. Surv., 21: 1003 (1968).

4. Frazier, T. M., Davis, G. H., Goldstein, H., and Goldberg, I. D.: Cigarette smoking and prematurity: A prospective study. Amer. J. Obstet. Gynecol., 81: 988 (1961).

5. Goldstein, H.: Factors influencing the height of seven-year old children: Results from the National Child Development Study. Human Biol., 43: 92 (1972).

6. Hardy, J., and Mellits, E. D.: Does maternal smoking during pregnancy have a long-term effect on the child? Lancet, ii: 1332 (1972).

7. Herriott, A., Billewicz, W. W., and Hythen, F. E.: Cigarette smoking in pregnancy. Lancet, $i: 771$ (1962).

8. Kullander, S., and Kallen, B.: A prospective study of smoking and pregnancy. Acta Obstet. Gynecol. Scand., 50: 83 (1971).

9. Lowe, C. R.: Effects of mothers' smoking habits on birth weight of their children, Brit. Med. J. 2: 673 (1959).

10. Maternal nutrition and the course of pregnancy: Summary report: Committee on maternal nutrition, Food and Nutrition Board, National Research Council, National Academy of Sciences, Washington, D.C. Superintendent of Documents. United States Printing Office, Washington, D.C., (1970)..

11. Miller, H. C.: Unpublished studies.

12. Miller, H. C., and Hassanein, K.: Diagnosis of impaired fetal growth in newborn infants. Pediatrics, 48: 411 (1971).

13. Miller, H. C., and Hassanein, K.: Fetal malnutrition in white newborn infants: Maternal factors. Pediatrics, 52: 504 (1973).

14. Miller, H. C., and Hassanein, K.: Maternal factors in "fetally malnourished" black, newborn infants. Amer. J. Obstet., Gynecol., 118(1): (1974).

15. Mulcahy, R., Murphy, J., and Martin, F.: Placental changes and maternal weight in smoking and non-smoking mothers. Amer. J. Obstet. Gynecol., 106: 703 (1970).

16. O'Lane, J. M.: Some fetal effects of maternal cigarette smoking, Obstet. Gynecol., 22: 181 (1963).

17. Peterson, W. F., Morese, K. N., and Kaltreider, D. F.: Smoking and prematurity: A preliminary report based on study of 7,740 Caucasians. Obstet. Gynecol. 26: 775 (1965).

18. Reinke, W. A., and Henderson, M.: Smoking and prematurity in the presence of other variables. Arch. Environ. Health, 12: 600 (1966).

19. Rohrer, F.: Der index der Korperfulle als Mass dess Ernahrungszustandes. Munch. Med. Wschr., 68: 580 (1921). 
20. Sargent, D. W.: Weight-height relationship of young men and women. Amer. J. Clin. Nutr., 13: 318 (1963).

21. Savel, L. E., and Roth, E.: Effects of smoking in pregnancy: A continuing retrospective study. Obstet. Gynecol., 20: 313 (1962).

22. United States Public Health Service: The Health Consequences of Smoking: A Report of the Surgeon General: 1972 (United States Government Printing Office, Washinton, 1972).

23. Underwood, P. B., Kesler, K. F., O'Lane, J. M., and Callagan, D. A.:
Parental smoking empirically related to pregnancy outcome. Obstet. Gynecol., 29: 1 (1967).

24. Yerushalmy, J.: Mother's cigarette smoking and survival of infant. Amer. J. Obstet. Gynecol., 88: 505 (1964).

25. Requests for reprints should be addressed to: H. C. Miller, M.D., Departments of Pediatrics and Biometry, University of Kansas Medical Center, 39th St. at Rainbow Blvd., Kansas Cith, Kan. 66103 (USA). 26. Accepted for publication July 26, 1974
Albumin bilirubin $\mathrm{pH}$

\title{
Effect of $\mathrm{pH}$ on the Interaction of Bilirubin with Albumin and Tissue Culture Cells
}

\author{
THOMAS NELSON, JøRGEN JACOBSEN, AND RICHARD P. WENNBERG ${ }^{(52)}$ \\ Department of Pediatrics, Division of Neonatal Biology, University of Washington, Seattle, Washington, USA
}

\section{Extract}

Titrations of albumin with bilirubin were performed at $\mathrm{pH}$ 7.0 and $\mathrm{pH}$ 7.4. Unbound bilirubin concentrations were determined using a horseradish peroxidase assay. Titrations of infant serum indicated that $1 \mathrm{~mol}$ bilirubin was bound tightly/mol albumin at either $\mathrm{pH}$ with an association constant of approximately $6.2 \times 10^{7} \mathrm{M}^{-1}$. When binding occurred at secondary sites, data were more scattered, but no $\mathrm{pH}$ differences could be detected. The effect of bilirubin on cells was studied by determining the viability of plated $L$ cells after a pulse of bilirubin. The lethal unbound bilirubin concentrations for $50 \%$ of cells at $\mathrm{pH} 7.4$ was about $0.7 \mu \mathrm{M}$ compared with $0.3 \mu \mathrm{M}$ at pH 7.0. Cell uptake of unbound bilirubin was rapid at either $\mathrm{pH}$. In the essential absence of albumin (20/1 molar ratio), about $66 \%$ of the added bilirubin appeared in the cell pellet in $10 \mathrm{~min}$ at $\mathrm{pH} 7.0$; initial uptake at $\mathrm{pH} 7.4$ was 44\% $(P<0.001)$.

Our data do not support the hypothesis that acidemia decreases albumin binding of bilirubin. The increased sensitivity appeared to be related to a greater cell uptake of bilirubin at the lower $\mathrm{pH}$.

\section{Speculation}

Although albumin binding of bilirubin is clearly an important factor in the pathogenesis of kernicterus, this study emphasizes the importance of cell-bilirubin interaction as a determinant of bilirubin distribution and toxicity. Intervention to decrease the serum bilirubin concentration in a jaundiced neonate must respond both to the status of albumin-bilirubin binding and to conditions which alter the cellular affinity for bilirubin.

The peroxidase method provides a sensitive new technique for analyzing protein bilirubin interaction.
Jaundiced infants with low plasma $\mathrm{pH}$ appear to have an increased risk of developing bilirubin encephalopathy $(19,20)$. This clinical observation is supported by experimental work in organ (39) and tissue (12) culture showing increased cell damage at low $\mathrm{pH}$, and by animal experiments which have demonstrated an increased brain : uptake of bilirubin in acidemic guinea pigs (16) and increased CSF bilirubin in acidemic rabbits (38). A decreased $\mathrm{pH}$ has also been shown to enhance the uptake of bilirubin by erythrocytes and mitochondria when incubated in media containing albumin $(3,32)$.

The increased toxicity of bilirubin at low $\mathrm{pH}$ has been attributed to a decrease in albumin binding of bilirubin $(3,11$, $28,32,33)$. However, supporting experimental evidence for decreased binding within the physiologic $\mathrm{pH}$ range is conflicting, and the possibility exists that cells may be more sensitive to bilirubin at low $\mathrm{pH}(12,16,39,45)$. As measurements of serum albumin binding and unbound bilirubin are becoming utilized increasingly in managing jaundiced infants, the effect of $\mathrm{pH}$ on albumin binding and bilirubin distribution is of practical as well as theoretical importance.

The following experiments examine whether the increased bilirubin toxicity in cell culture at low $\mathrm{pH}$ is due to a decrease in albumin binding or to an increased cell sensitivity to bilirubin.

\section{METHODS}

\section{CELL TOXICITY}

Strain L-929 cells (46) were grown under $5 \% \mathrm{CO}_{2}$ and air in Eagle's minimal essential medium containing Hanks' balanced salt solution and 5\% fetal calf serum. The Hanks' solution was modified by substituting glutamine, $350 \mathrm{mg} /$ liter, for glucose, and HEPES, $25 \mathrm{mEq} /$ liter, for sodium bicarbonate, and adjusting to $\mathrm{pH} 7.4$ with sodium hydroxide. Cells were 